\title{
SURVIVAL OF BANGLADESH ECONOMY DURING COVID-19 RECESSION WITH THE USE OF TECHNOLOGY : AN APPLICATION OF KEYNESIAN APPROACH
}

\author{
Md. Mehedi Hassan Onik \\ Lecturer \\ Department of Computer Science \\ American International University-Bangladesh, Dhaka-1229, Bangladesh \\ E-mail: mehedi.onik@aiub.edu \\ Md. Siyamul Islam \\ Lecturer \\ Department of Computer Science \\ American International University-Bangladesh, Dhaka-1229, Bangladesh \\ E-mail: siyamul@aiub.edu \\ Md. Manzurul Hasan \\ Assistant Professor \\ Department of Computer Science \\ American International University-Bangladesh, Dhaka-1229, Bangladesh \\ E-mail: manzurul@aiub.edu

\begin{abstract}
Ashraf Uddin
Assistant Professor

Department of Computer Science

American International University-Bangladesh, Dhaka-1229, Bangladesh

E-mail:dr.ashraf@aiub.edu
\end{abstract}

\begin{abstract}
The Covid-19 (coronavirus) crisis is severe, and will have a horrendous financial and economic effect on all over the world. Consequently, this pandemic has jeopardized the rising economy of Bangladesh. The country's economy largely depends on Ready-made Garments, remittances, and export of agricultural products. In response to this unusual 'Great Recession', Bangladesh is exploring the use of technologies to fight back this recession amidst the ongoing social distancing, self-isolation and travel limitations. This study critically analyzes and explores the financial policies adapted by the Bangladesh government. The study identifies that the government is applying Keynesian approach and providing adequate incentives and subsidies in order to strengthen the economy. In addition, the study draws insight into how the government is spending a significant amount on Information and Communication Technology (ICT) and popularizing ICT platforms to uphold financial activities. It also elaborates on the implications of a huge government budget in several sectors through ICT. However, the government slightly misuses the budget by allying with corruption and money laundering. Finally, the study
\end{abstract}


successfully advocates that, although the Keynesian approach invites issues like debt, inflation, and unemployment but the government prefers the Keynesian approach (direct assistance or subsidies from the government) to protect Bangladesh economy.

Keywords: Bangladesh, Coronavirus, Developing Country, Information Technology, Recession.

JEL Classification Codes: O14, O16, O23, O33.

\section{INTRODUCTION}

The abrupt and huge shock of the coronavirus pandemic has already ruined the global economy. According to the report provided by the World Bank and International Monetary Fund (IMF), the global economy has been contracted by 5.2\% in the year 2020 (The World Bank, 2020; IMF, 2020). The world has not experienced this kind of financial blow (global recession) since World War 2. Almost all the countries had to maintain a strict lockdown in 2020 resulted in extra spending by their Governments. To be more specific, the countries whose economies mostly depend on export, tourism, global commodity trade, sports-athletics, foreign aid, transports and travelling industries etc. are largely affected by this dreadful pandemic. IMF compares this recession with the great depression of the 1930s and has published data related to the global growth in a report (IMF, 2020). The report clearly states that developed countries like Canada, Unites States of America, the United Kingdom, Japan, France, Italy, Germany, and India had negative GDP growth $(-5 \%$ to $-75 \%)$ in the year 2020 whereas, countries like China, Vietnam, South Korea, Egypt, Iran, Mongolia experienced slightly positive GDP growth (1\% to $10 \%$ ) (IMF, 2020). KPMG reported that the Chinese economy survives by taking drastic measures in sectors like labor policy, trade restrictions, loans, debt payment, subsidy, tax etc.(KPMG, 2020).

Surprisingly, Bangladesh a third world developing country with an enormous population and fragile economic stability has experienced a GDP growth of 3.8\%, reported by IMF (2020). Govindraj Ethiraj of India Spend, a famous financial journalist has recently taken an interview with Ahsan H. Mansur, chairperson of BRAC bank on $20^{\text {th }}$ October 2020 to identify the main factors and key reasons for Bangladesh's GDP growth despite this ongoing pandemic (Ethiraj, 2020). The interviewer outlined a few factors like uprising the use of information and communication technology, substantial government subsidy, steady garment export, gigantic foreign remittance, and good governance. Bangladesh government has gained tremendous boosts in the economy by keeping the garments industry open amidst this pandemic beside $20 \%$ upsurge of foreign remittance.

The term 'Recession' is nothing new to this world. Researchers around the world have invented several theories or models to fight back those blows over the years, for example, the 'Laissex faire' model, the Keynesian model and the Neoliberal models are few remarkable models (Berend, 2016; Peck et al., 2012; Tobin, 1975). Adam Smith promoted "laissez-faire" model and considers that since the market is open, people will make their course to fight back recession without any government intervention (Berend, 2016). Keynesian proposed just the opposite where he stated that the government must interfere and contribute to upholding the economy during this pandemic (Tobin, 1975). Finally, the neoliberal model proposed that economic and public policies must coincide all together to fight the recession in today's changing economy (Peck et al., 2012).

For several socio-economic factors, Bangladesh has adopted the Keynesian theory or approach during this global pandemic (Ahamed, 2021; Ali et al., 2021; Hasan et al., 2021; Islam 
et al., 2020). Although the Keynesian model supports a limited period of time, the Government subsidized billions to keep the market steady to sustain its popularity (Vickrey, 1948). However, the matter of fact is that the current government also utilized this recession and bulk monetary disposal of government money to bail out government debt and associated corruptions. Over the last decades people from all sectors are fascinated with the ICT sectors. Nevertheless, the Bangladesh government efficaciously utilizes this uprising sector to improvise the Keynesian economy to uphold the growth of Bangladesh economy (GDP) (Ahamed, 2021; Ali et al., 2021; Ashraf et al., 2017; Lim et al., 2020; Naym \& Hossain, 2016; Sethi et al., 2020). This study critically analyzes the Keynesian model and how the Bangladesh government is utilizing and improving the ICT sector to eradicate ongoing recession. The key contributions of this study are mentioned here.

- Exploration of different recession fighting models to identify the model has been picked by Bangladesh.

- Identification of the tricks and tactics that how Bangladesh government is imposing technology adoption at mass level to eradicate recession.

- Finally, outlines of the limitations and ill-governance related consequences from the technique followed by the government to eradicate recession.

\section{BACKGROUND STUDY \\ Currently Practiced Recession Prevention Models \\ Keynesian Approach}

During the great depression of 1930, John Maynard Keynes generated the idea of this Keynesian economics where accomplishing the common demand for a short period was the key idea (Romana, 2020; Tobin, 1975; Vickrey, 1948). Keynesian advocated that increasing government expenditure along with decreasing of Tax or VAT can significantly grow the overall economy of a country. With the key concept of 'government should increase demand to boost growth. The theory can be further explained like this if collective need in a particular economy goes down, this causes failing in production which results in unemployment, truncated pricing and low wages. If a Keynesian theory can keep inflation and wages to a limit, owners fund heavily to hire additional workers this result in stimulating employment and restoring the overall economic growth. A real example can be US President Barak Obama who followed the path of his predecessor President Roosevelt and avoid the economic model of President Ronald Reagan and Bill Clinton (Bartels, 2013; Douglass, 2010). Obama ended the great recession of his tenure by allowing an enormous stimulus Act. He imposed the Keynesian theory by spending more on education, healthcare and in-house heavy machinery production (Lewis-Beck \& Nadeau, 2009).

\section{Laissex Faire' Model}

With an actual meaning of 'leave alone', this economic model proposed by Adam smith discourages government involvement in the economy. That is, the economy blooms automatically, which results in automatic employment and production. This model encourages the idea of free-market capitalism which resists interference from the state. However, real needy people might experience extreme poverty (Berend, 2016; Soll, 2020).

\section{Neoliberal Model}

The neoliberal model is all about free trade. This model mostly matches with the laissex-faire economics model where there exists a very limited government interference. Therefore, market, 
business, trade, stock, capitalism policy etc. are mainly automated with minor effects from authorities. Conservative politicians like British Prime Minister Margaret Thatcher (1979-90) and U.S. President Ronald Reagan (1981-89) followed this model to fight back recession. There is no fixed model for this neoliberal model that is why economist like Adam smith blamed the government as an 'invisible handle'. Besides, Adam smith also suggested following a kind of liberalism where only minimal level governance will be there (López-Andreu \& Verd, 2020; Peck et al., 2012).

\section{Characterization of Bangladesh Economy}

This part of the study outlines the major properties and facts related to the Bangladesh Economy.

\section{Uneven Economic Growth}

Organizations like IMF, World Bank, Asian Development Bank (ADB) have already raised questions regarding the authenticity of the astonishing economic growth of Bangladesh. A study reported that the uneven economic development index of Bangladesh was 7.64 out of 10 during the year 2007-2020 which is alarming (Bangladesh Economic Indicators, 2021; Hasnath, 2020; Miah \& Majumder, 2020). The figure (Figure 1) represents the uneven economic development index for the last 10 years. Government intuitively increases the factors like GDP while the per capita income was not improved much (Bangladesh Economic Indicators, 2021; Hasnath, 2020; Miah \& Majumder, 2020).



Figure 1. Uneven Economic Development Index of Bangladesh (2011 - 2020)

\section{Tax Evasion}

Bangladesh economy was actively criticized by the World Bank by mentioning that its tax system and associated institutions are heavily corrupted and must improve as soon as possible. Both direct and indirect Taxes are being envisioned (Fahim \& Kabir, 2021; Nurunnabi, 2019). Therefore, Tax income cannot contribute much to overall GDP which is also alarming. Unusually, Bangladesh has the least amount of total tax revenue as a percentage of GDP in South Asia during the year 2003-2020. In the year 2016, the tax revenue to GDP was $8.77 \%$ in Bangladesh, 12.29\% in Nepal 18.69\% in Nepal, 8.84\% in Afghanistan, and $12.29 \%$ in Sri Lanka (Fahim \& Kabir, 2021; Hasnath, 2020). However, both government and the National Board of Revenue (NRB) failed to tackle tax evasion in Bangladesh due to a lack of policy and will power. 


\section{Too Much Poor and Rich People}

The rise in the inequality in income distribution has risen significantly in the last decade. Poor people are getting poorer and rich are getting richer (The World Bank, 2020; Uttom \& Rozario, 2019; Zhao et al., 2019).

\section{Corruption in Each Level of Governance}

A real dark part of the Bangladesh economy is losing a significant amount of money for corruption and associated mismanagement for government expenditure (Kabir, 2021).

\section{Money Laundering}

A real dark part of the Bangladesh economy is losing a significant amount of money for corruption and associated mismanagement for government expenditure (Kabir, 2021; Solaiman, 2018).

\section{Lack of Qualified Human Resources}

As the countries education and hiring policy is questionable, so it has also been noticed that in almost all sectors top managements are hired from abroad (Alauddin \& Chowdhury, 2015).

\section{Fragile Foreign Policy}

This country also has a weak foreign policy. It has been recently noticed that several economic treaties have been made with India which goes against Bangladesh. Besides, several industries and products of Bangladesh cannot grow due to the easy availability of its competitors from India (Dietrich et al., 2018; Winters et al., 2017).

\section{The Emergence of ICT}

Lastly, the economic paradigm of Bangladesh is being shifted through the massive use of ICT in each sector. People are adopting this sparingly. Business, society, cultural, agricultural, financial etc. sectors are improving at a geometric rate (Aziz, 2020).

\section{Limited Sources of Income}

The entire economy and a lion share of overall GDP of Bangladesh depend on these four factors.

\section{Foreign Aid}

The government depends highly on foreign aid for accomplishing the giant budget. Whether it is making a bridge, road, food, health government heavily dependent on foreign aid or loan (Dietrich et al., 2018). This also brings a million foreign debts to the country.

\section{Agriculture}

Although the Agriculture sector cannot contribute much to the economy, however, a large portion of foods is produced in house in Bangladesh. Besides, a major portion of people in Bangladesh depends on farming directly or indirectly (Seymour et al., 2020).

\section{Readymade Garments (RMG)}

The readymade garments (RMG) sector of Bangladesh is highly appreciated all over the world. The country earns a fortune from this sector since the minimum wages of Bangladesh is very low (Islam, 2020a). 


\section{Remittance}

Since a lot of Bangladesh citizen lives temporary or permanent in abroad, the country receives a significant amount of remittance from abroad. Recently, after easing the policy and introducing the technology, the country's foreign reserve has suppressed al previous records (Barai, 2020).

\section{HOW BANGLADESH IMPLEMENTS THE KEYNESIAN APPROACH TO TACKLE}

\section{Recession through Technology Adoption}

This section describes and elaborates how the Bangladesh government subsidizes millions during this coronavirus (Covid-19) period to fight back the global recession (Ali et al., 2021; Tobin, 1975). A sector-wise plan, policy and financial stats are provided herewith.

\section{Mobile Banking}

The novel coronavirus has brought a wind of change in almost every sector of human life along with financial and banking sectors. The importance and acceptance of mobile banking have increased dramatically during the Covid-19 pandemic in Bangladesh, though it was firstly introduced in 2011 by Dutch Bangla Bank (Al Amin et al., 2021; Lee et al., 2021). As people were unable to go outside for lockdown, the transaction through mobile banking was one of the lifelines to mobilize the economy and make a living. The total number of mobile banking users is $8,51,29,067$ currently in Bangladesh. But all the mobile banking users were not active before the pandemic. Statistics show that transactions along with new users have increased exponentially during the Covid-19 period. Along with the aforementioned reasons, the Government used mobile banking to distribute incentive packages such as payment of garments workers, helping 5 million poor families who were jobless due to corona and so on. The government disburse 12 billion in cash aid for the poor families by coronavirus via mobile banking. Various institutes, small business corporations, as well as banks having no mobile banking facilities, came into long term agreement with mobile banking giants like bKash, Rocket and Nagad (Al Amin et al., 2021; Lee et al., 2021). Table 1 illustrates the Mobile Financial Services (MFS) that occurred between February and August 2020 (Mobile Finance System, 2020).

Table 1. Mobile Financial Services (MFS) comparative summary statement of February to August 2020.

\begin{tabular}{|c|c|c|c|c|c|c|c|}
\hline Description & February & March & April & May & June & July & August \\
\hline $\begin{array}{l}\text { No. of MFS } \\
\text { Services }\end{array}$ & 15 & 15 & 15 & 15 & 15 & 15 & 15 \\
\hline No. of agents & 985,914 & 992,658 & 999,481 & 996,413 & 998,504 & $1,003,005$ & $1,009,430$ \\
\hline $\begin{array}{l}\text { Registered } \\
\text { clients in lac }\end{array}$ & 818.57 & 825.76 & 849.77 & 879.39 & 887.97 & 925.73 & 929.37 \\
\hline $\begin{array}{l}\text { Active } \\
\text { accounts in } \\
\text { Lac* }\end{array}$ & 270.87 & 268.45 & 280.91 & 354.61 & 385.71 & 426.78 & 405.73 \\
\hline $\begin{array}{l}\text { No. of total } \\
\text { transaction }\end{array}$ & $\begin{array}{l}226,109,40 \\
5\end{array}$ & $\begin{array}{l}235,858,51 \\
4\end{array}$ & $\begin{array}{l}217,564,95 \\
0\end{array}$ & $\begin{array}{l}281,780,66 \\
2\end{array}$ & $\begin{array}{l}256,097,77 \\
2\end{array}$ & $\begin{array}{l}310,442,38 \\
0\end{array}$ & $\begin{array}{l}269,697,87 \\
5\end{array}$ \\
\hline $\begin{array}{l}\text { Total } \\
\text { transaction } \\
\text { (crore BDT) }\end{array}$ & $41,334.79$ & $39,785.23$ & $29,029.14$ & $47,601.28$ & $44,830.66$ & $62,999.42$ & $41,403.82$ \\
\hline $\begin{array}{l}\text { No. of daily } \\
\text { average }\end{array}$ & $7,796,876$ & $7,608,339$ & $7,252,165$ & $9,089,699$ & $8,536,592$ & $10,014,270$ & $8,699,931$ \\
\hline
\end{tabular}




\begin{tabular}{|l|l|l|l|l|l|l|l|}
\hline transaction & & & & & & & \\
\hline $\begin{array}{l}\text { Average } \\
\text { daily } \\
\text { transaction } \\
\text { (in crore } \\
\text { BDT) }\end{array}$ & $1,425.34$ & $1,283.39$ & 967.64 & $1,535.53$ & $1,494.36$ & $2,032.24$ & $1,335.61$ \\
\hline
\end{tabular}

Which is constructed based on the data given by Bangladesh Bank (Mobile Finance System, 2020) from table 1 data we can observe that all the components mentioned in the first column got a higher amount in April 2020 than other months. After April, it shows a fall in transactions in the month of May and July and again it became normal in June and august. Table 2 illustrates product-wise change information between a couple of months from February to August 2020 for MFS in Bangladesh (Mobile Finance System, 2020). From the table (Table 2), we can observe that the change is very sharp in between the month of April - May and June July.

Table 2. Product-wise change information between two months from February to August, 2020

\begin{tabular}{|l|c|c|c|c|c|c|}
\hline Product Name & Feb-Mar & Mar-Apr & Apr-May & May-Jun & Jun-Jul & Jul-Aug \\
\hline Inward Remittance & $5.50 \%$ & $255.30 \%$ & $58.40 \%$ & $-29.60 \%$ & $35.40 \%$ & $-38.20 \%$ \\
\hline Cash-In transaction & $-5.90 \%$ & $-36.70 \%$ & $50.20 \%$ & $-6.70 \%$ & $39.80 \%$ & $-32.80 \%$ \\
\hline Cash-Out Transaction & $-5.20 \%$ & $-36.70 \%$ & $68.50 \%$ & $-3.10 \%$ & $42.50 \%$ & $-32.30 \%$ \\
\hline P2P transaction & $0.70 \%$ & $-6.30 \%$ & $60.30 \%$ & $-11.40 \%$ & $31.70 \%$ & $-27.90 \%$ \\
\hline $\begin{array}{l}\text { Salary Disbursement } \\
\text { (B2P) }\end{array}$ & $14.60 \%$ & $-14.60 \%$ & $108.30 \%$ & $7.20 \%$ & $93 \%$ & $-76.80 \%$ \\
\hline $\begin{array}{l}\text { Utility Bill Payment } \\
\text { (P2B) }\end{array}$ & $-1.80 \%$ & $-37.40 \%$ & $120.50 \%$ & $66 \%$ & $-11.50 \%$ & $3.40 \%$ \\
\hline Merchant Payment & $-18.20 \%$ & $-50.90 \%$ & $100.20 \%$ & $73.50 \%$ & $39.80 \%$ & $-6.50 \%$ \\
\hline Government Payment & $-55.40 \%$ & $-40 \%$ & $971.30 \%$ & $-54.50 \%$ & $200.10 \%$ & $-98.60 \%$ \\
\hline Others & $8.80 \%$ & $28.70 \%$ & $45.50 \%$ & $-12.20 \%$ & $18.50 \%$ & $-18.10 \%$ \\
\hline
\end{tabular}

\section{Digital Payment}

Like many other countries in the world, Bangladesh has witnessed a rapid growth of digital payment during the Covid-19 pandemic because of continuous lockdown, people had to be familiar with various digital systems (Srouji, 2020). The data released by Bangladesh Bank shows that credit card transactions increased to 23.68 percent year-on-year to BDT 12,200 million in September 2020. The debit card transactions grew 14.59 percent year-on-year (Al Amin et al., 2021). Despite rapid growth in recent years, only 29 percent of transactions are carried out digitally in Bangladesh (Bangladesh Bank, 2020) (Figure 2). 


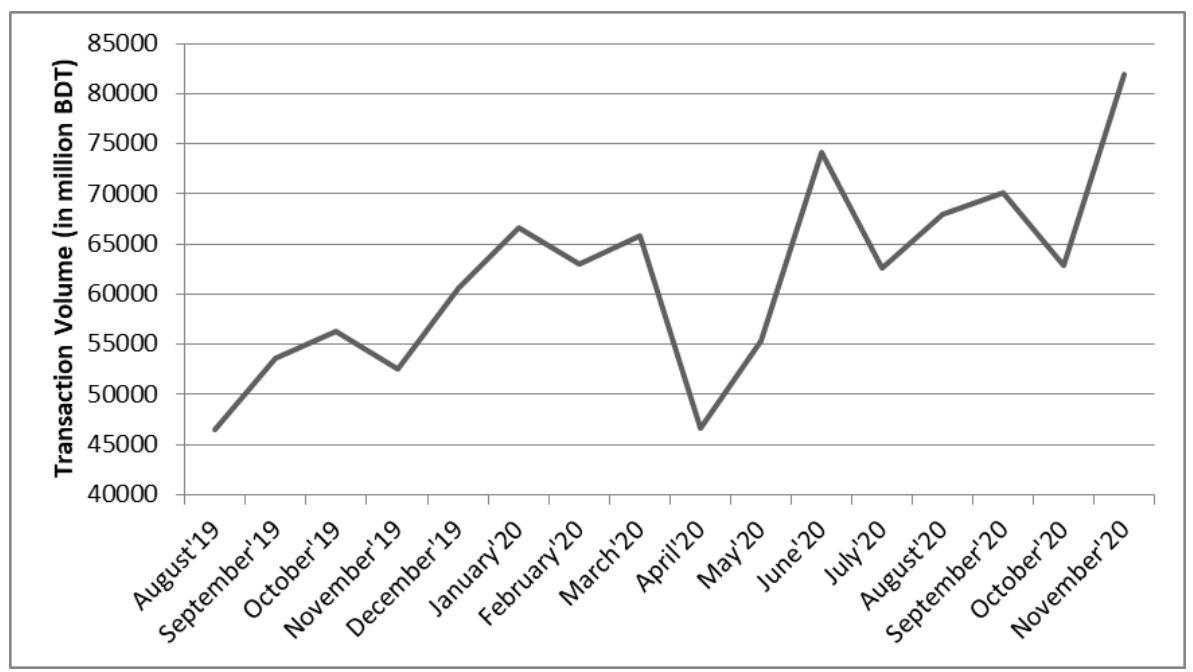

Figure 2. Trend of internet banking transaction volume (in million BDT) (Bangladesh Bank, 2020)

Figure 2 shows the trend of internet baking transaction from August'19 to November'20. The figure clearly depicts that there is a steady growth in Covid-19 period effectively from April'20.

Thus, the financial technology has a vast impact on the digital payment system. Since globally financial technology is leading the expansion in digital payment, Bangladesh needs to adopt financial technology innovations. To ease the cost of the transaction and minimize the security risk factors Bangladesh should introduce new technology like Blockchain. To promote digital payment, the government should take steps to shrink the use of cash. A study by the Boston Consultancy Group (BCG) shows that digital payments could add 3 percent to the overall GDP of a country thus boosting the economy (Stern \& Deimler, 2006). Moreover, Big data technology with artificial intelligence can be a useful tool to stop fraudulent cases in the digital payment system.

\section{Education}

Online Education at all level from preschool to university everything is done via digital communication tool (Ramij \& Sultana, 2020). Bangladesh government has utilized digital communication platform like zoom, Teams, Google classroom, YouTube, Facebook etc. for continuing education amidst corona outbreaks (Dutta \& Smita, 2020). Even in rural areas with mobile internet $(4 \mathrm{G})$, government and private education institutions successfully operated online education. This technique helps both students and teachers. The government also propagated in favor of online education through television media, so that rural people also embrace this technological revolution.

Although several other sectors had cut a lot of jobs, educational institutions were different where school, college and universities operated in the online version. So, digital platforms are saving the job of thousands of teachers in Bangladesh and keeping the overall education economy up reported by UNICEF (Chowdhury, 2020). 
The government recently invested millions to establish infrastructure like a language lab, train faculties, launch high performing computer lab, connect high-speed internet, inaugurate digital classroom, science simulation software etc. (Sarker et al., 2019).

Internet has significantly improved the quality of the local learners which is allowing them to go abroad for higher studies as well (Rabbani et al., 2020). Finally, this study outlined a few tech-factors that are actively increasing internet usage in Bangladesh:

- Mammoth Youth Generation: More than $20 \%$ of the overall population of Bangladesh are youth. Intuitively, that young generation mostly relies on the internet for entertainment, business, communication, e-commerce, f-commerce, and education etc. purposes, thus the use of the internet has been significantly increased during the last few years (Naym \& Hossain, 2016).

- Having its Satellite: Bangabandhu Sattelite-1 provides a wide range of services for citizens like direct-to-home TV, radio, telemedicine, education and internet access etc. After this service's arrival overall internet and satellite television uses have aided the education sector significantly, especially in rural areas.

- Online platforms, especially during this coronavirus period, are becoming more popular with public and private bodies, and subsidies on internet prices are being provided subject to use for the educational purpose (Rabbani et al., 2020).

- Digital Classroom: Students are using PowerPoints, learning from foreign teachers, practicing and simulating software only because of this technology (Lim et al., 2020; Rabbani et al., 2020).

\section{Telemedicine}

Telemedicine is very famous in Bangladesh nowadays. During the lockdown, except for major critical issues all the patients take medical services over telemedicine. Even nowadays many people feel comfort to use telemedicine rather than physical appointment. Doctors also suggest their patients to consult remotely. People use WhatsApp, IMO, and Messenger etc. to make appointments with the physicians. It supports a lot in Bangladesh economy, also serves in the unemployment problem. Without the proper use of the internet and different tools telemedicine is quite impossible. Diagnostic centers take orders to collect samples from homes and delivery reports over e-mails. Call centers and different alternative payment channels helped a lot in this connection. Many hospitals keep their call centers opened 24 hours 7 days with sufficient doctors. Many telemedicine companies were launched as startups, which is a very good sign in the economy. To provide the services available in the rural areas and in villages many ISPs, Cyber cafes and technical training centers were launched that can be treated as new startups, help us a lot in unemployment problems. Mass people share preliminary treatments through Facebook as fundamental treatments of common diseases like fever and cold. Using these supports many individuals got benefitted. It helps the poor a lot from massive expenditures and fuel consumptions to rush hospitals. That is not very far when all the medical facilities would be possible to come up with tele and remote services. A guideline on telemedicine during the Covid-19 pandemic has recently been published (Corona Info Bangladesh, 2020). Finally, Bangladesh government has launched an online portal to serve telehealth and to broadcast the status of the Corona outbreak (Chowdhury et al., 2021; Corona Info Bangladesh, 2020).

\section{Use of Digital Media}

People get day to day, time to time news on Covid-19 infections over different media channels 
like televisions, news portals, call centers, broadcast messages. People also came to know which services are available at which locations on different facilities. That was a very critical situation, a nation observed during Mach-May 2020. People also got refreshed over these mass media channels. Social media keeps the people up mentally, socially, and emotionally. These are always direct and indirect parameters in the economy of a country. Since people avoided keeping physical newspapers the companies started to give the services in electronic form. Children continue their education by using smart devices and they keep interactions and communication with friends, relative and neighbors virtually. Without these facilities, it might be a massacre for the young generation to be mentally broken down. Not all benefits can always be scaled in term monetary value. Different TV channels broadcast lecture series that help very much to utilize the best use of time of the children (UNICEF, 2020).

\section{Rising Smart Device or Technology Sell}

Since all the services came in virtual or in online form, the selling rates of smart phones have been accelerated. Even the school-goers needed dedicated smart phones or laptops to maintain smooth education. This enhances good currency flow in electronic market. Many businessmen opened different electronic devices shops to survive. E-Commerce, m-commerce, and fcommerce helped the people to come forward with new startups on different products (Parvin et al., 2021). Startups are not only on new products but also sometimes on secondhand products. Rate of secondhand products has also been increased. Because a big number of people is leaving cities for villages only due to consecutive lockdowns and jobs are becoming online rather than physical presence. Mobile banking's support in the economy MUST be mentioned (Al Amin et al., 2021). People got services from credit cards at all kinds of emergency issues.

\section{Outsourcing and Freelancing}

As the severity of Covid-19 increased, the private companies had no way to stop their business but to allow employees to work from home. In pre-pandemic time, approximately five percent of full-time employees with office jobs worked primarily from home. That has become 20-30 percent in the new normal in the Covid-19 pandemic although there is variation across occupations and industries (Levanon, 2020). As Bangladesh was forced into a 10-day-long holiday from March 26 due to the ongoing coronavirus pandemic, most private companies had asked employees to work from home to keep their operations running (Islam et al., 2020). More or less, all working in the country's private sector, including experts, have welcomed this initiative. They believe this gives them a better chance to fight the virus, remaining uninfected. This has become possible due to emerging software which facilitates sharing and discussing from remote. Private universities continued academic activities by going online in shut down. Teachers and students were introduced to different tools to adopt online mode of classes. Thus, the financial activities in education sectors remained unharmed. Although some universities cut salaries of teachers but the job lost was very insignificant in the sector (Dutta \& Smita, 2020; Islam et al., 2020; Rahman et al., 2020). Besides, govt. has also trained millions of youths with advanced IT knowledge (Al Amin et al., 2021; Al Omar et al., 2019; Hossain et al., 2020). This sector is eradicating unemployment issue drastically as almost 650000 registered freelancers are earning almost 100 million USD annually. E-Cab advisory council member Nahim Razzaq, MP, said the e-commerce industry has massive potential. "I think the industry $\$ 1.3$ billion right now. Some 2,000 e-commerce entrepreneurs are engaged here. We'll get good results in the future if we all work together," he believed (Zaman, 2019; Bhattacharyya et al., 2020). Even during this 
coronavirus, when the overall economy of Bangladesh went down, a sector like freelancing in ICT sector earned plenty of foreign currencies. Although, Syed Almas Kabir, president of BASIS and CEO of Metro Net Bangladesh Ltd, indicated that the country's ICT industry already lost about USD 1.3 billion due to the coronavirus (Zaman, 2019; Bhattacharyya et al., 2020; Zakirdjanovich, 2021). Finally, this study outlined a few tech-factors those are actively increasing the outsourcing and freelancing market industry in Bangladesh:

- Government Awareness: Recently government is funding for organizing idea contest, providing start-up incubators, arranging ICT expo a, organizing hackathons etc. those are encouraging freelancers (Ashraf et al., 2017; Bhattacharyya et al., 2020; Kano et al., 2021).

- Policy Awareness: Government is also easing payment, recognition and licensing policies etc. Government-approved software association (BASIS) reformed few policies like seven-year tax excuse for authorized IT organizations; VAT for e-commerce has reduced to zero, easy payment method, free incubators for start-ups etc.

- Availability of Infrastructure: In last decades the whole country improved the quality of ICT educators, the performance of the computer, availability of the software, availability of high-speed internet, social recognition, payment method, minimum wages etc. Thus, freelancing will surely be the pivotal force on Bangladesh economy (Amin \& Rahman, 2019).

\section{Research, Sustainable Development and Digital Governance}

To talk about research, many publishers and universities made their repositories open to download a very good number of papers without any cost during lock-down, even still now (Sakil, 2018; Sarker et al., 2018). Since most of the universities are still operating their academic works over online like Zoom, MS Teams etc., the intellectual communities are staying at home. It has been contributing directly or indirectly in commercial markets as well as in the financial markets. It is obviously worthy to mention that outcome from any scientific paper like physical science and biological science can never be metered in the scale of money. Outcome of vaccine is also from the works of intellectuals.

\section{Remittance Industry}

Millions of Bangladeshi has been migrated to abroad in search of a living. This migration trend has been directly affected by the remittance of Bangladesh. A significant portion of the total GDP of Bangladesh (around $15 \%$ ), is contributed from remittance. Low labor cost, availability, efficiency, adaptability and low life expectancy etc. are the driving forces for the huge demand of Bangladeshi workers in foreign countries.

So, the current government is promoting digital payment, reducing transaction cost, creating more money withdrawal point and introducing new tech-policy to increase the foreign reserve of Bangladesh (Islam, 2020b; Islam et al., 2017; Moniruzzaman, 2020).

Money sending trends have been noticed due to Corona-virus outbreak. People are also investing that money in Bangladesh since investing via a digital platform is also possible these days. In 2020-2021 fiscal year wage earner's remittance has been increased drastically (Figure 3)(Bangladesh Bank Wage Remittance, 2020). 


\begin{tabular}{|c|c|c|}
\hline \multirow{2}{*}{ Year/Month } & \multicolumn{2}{|c|}{ Remittances } \\
\hline & In million US dollar & In billion Taka \\
\hline $2020-2021 *$ & 12944.75 & 1097.84 \\
\hline $2019-2020$ & 18205.01 & 1543.52 \\
\hline 2018-2019 & 16419.63 & 1380.07 \\
\hline $2017-2018$ & 14981.69 & 1231.56 \\
\hline $2016-2017$ & 12769.45 & 1010.99 \\
\hline $2015-2016$ & 14931.18 & 1168.57 \\
\hline 2014-2015 & 15316.91 & 1189.93 \\
\hline $2013-2014$ & 14228.26 & 1105.84 \\
\hline $2012-2013$ & 14461.14 & 1156.47 \\
\hline $2011-2012$ & 12843.43 & 1018.82 \\
\hline $2010-2011$ & 11650.32 & 829.91 \\
\hline $2009-2010$ & 10987.40 & 760.11 \\
\hline 2008-2009 & 9689.26 & 666.77 \\
\hline $2007-2008$ & 7914.78 & 542.96 \\
\hline $2006-2007$ & 5998.47 & 413.01 \\
\hline $2005-2006$ & 4802.41 & 322.76 \\
\hline 2004-2005 & 3848.29 & 236.48 \\
\hline $2003-2004$ & 3371.97 & 198.70 \\
\hline $2002-2003$ & 3061.97 & 177.29 \\
\hline 2001-2002 & 2501.13 & 143.77 \\
\hline $2000-2001$ & 1882.10 & 101.70 \\
\hline $1999-2000$ & 1949.32 & 98.07 \\
\hline 1998-1999 & 1705.74 & 81.98 \\
\hline $1997-1998$ & 1525.43 & 69.35 \\
\hline $1996-1997$ & 1475.42 & 63.00 \\
\hline 1995-1996 & 1217.06 & 49.70 \\
\hline 1994-1995 & 1197.63 & 48.14 \\
\hline 1993-1994 & 1088.72 & 43.55 \\
\hline $1992-1993$ & 944.57 & 36.97 \\
\hline 1991-1992 & 849.66 & 32.41 \\
\hline
\end{tabular}

Figure 3. From July 2016 Statistics Department, Bangladesh Bank \& up to June 2016 Foreign Exchange Policy Department, Bangladesh Bank.

During Covid-19 period, alike the whole world, Bangladesh is also experiencing a tough time. Remittance money came as a blessing, govt. as well as individuals are investing the remittance money to uphold the poor economy amidst corona pandemics. Foreign reserve goes really high even during this pandemic situation (Figure 3). The government was unable to provided 11.90 billion USD stimulus packages without the contribution of remittance supported by digital payment system (Bangladesh Bank Foreign Exchange Reserve, 2021). 


\begin{tabular}{|c|c|}
\hline & (In million US \$) \\
\hline Period & Reserves(Gross) \\
\hline \multicolumn{2}{|l|}{$2020-2021$} \\
\hline December & 42973.4 \\
\hline November & 41078.1 \\
\hline October & 40816.3 \\
\hline September & 39125.3 \\
\hline August & 38850.0 \\
\hline July & 37099.8 \\
\hline \multicolumn{2}{|l|}{ 2019-2020 } \\
\hline June & 35852.6 \\
\hline May & 33225.9 \\
\hline April & 32928.2 \\
\hline March & 32388.5 \\
\hline February & 32803.2 \\
\hline January & 32381.5 \\
\hline December & 32689.2 \\
\hline November & 31729.0 \\
\hline October & 32437.7 \\
\hline September & 31831.9 \\
\hline August & 32775.8 \\
\hline July & 32093.3 \\
\hline \multicolumn{2}{|l|}{ 2018-2019 } \\
\hline June & 32716.5 \\
\hline May & 31344.8 \\
\hline April & 32122.9 \\
\hline March & 31787.2 \\
\hline February & 32235.7 \\
\hline January & 31279.7 \\
\hline
\end{tabular}

Figure 4. Accounts \& Budgeting Department, Bangladesh Bank

Needless to say, the remittance industry is growing rapidly with the aid of advanced technologies. This study outlined a few tech-factors that are actively affecting the remittance industry in Bangladesh Islam; Srouji, 2020; Yesmin et al., 2019):

- Arrival and Availability of Internet: People of Bangladesh had to rely on the timeconsuming money transfer methods like demand drafts, manual money transfer, money orders, and hundi money transfer etc.

- The emergence of Mobile Finance: Beside bank's provided digital money transferring facility, local and international companies are also providing internet less mobile banking. Even underprivileged villagers are now getting advanced tech-facilities like SMS alerts, customer care services, operation in the local language (Bangla), mobile to bank and bank to mobile money transfer etc.

- Government Promoting Digital Payment: Bangladesh government is encouraging mass people to utilize the secure and easily accessible digital remittance related technologies by providing instant incentive, lowering internet price, making it available everywhere, lessening policies and regulations etc. 


\section{Agricultural Sector}

Technological facilities like smart farming, IoT based farming, online agriculture problem discussion forum etc. are getting popular here in Bangladesh. Government incentives and loans are mostly being distributed to the actual farmers through digital payment system. Irrigation water billing, electricity billing, soil quality monitoring etc. are being done using information and communication technologies. Nevertheless, aforementioned technologies are significantly lowering the overall farming expenditure of farmers. Finally, use of internet and associated mediums are providing farming related solutions of international standard. This study outlined a few tech-factors that are actively affecting the agricultural and farming industries in Bangladesh (Chowhan \& Ghosh, 2020; Rana et al., 2021).

- Distribution of incentives to actual farmers through digital payments is being only possible because of information technology.

- Farmers can use internet and digital platforms to get farming related solutions of international level immediately.

- Weather forecast, soil inspection, digital pest controlling mechanism, and product quality inspection facility can also be possible with technologies.

- By using digital platforms and ecommerce farmers are getting minimum price for their product which is boosting overall economy.

\section{DISCUSSION AND LIMITATIONS}

\section{Downside of following Keynesian Approach in Bangladesh}

Although current Bangladesh government technically overcome the coronavirus related great recession by subsidizing a gigantic amount of money mostly in technological sector. Although Keynesian recession fighting method carries advantages, it brings drawbacks like these (Anchal, 2020; Romana, 2020; Tobin, 1975; Vickrey, 1948).

\section{National Debt Increases Irrationally}

In order to subsidize almost every sector by empowering information technology, current government had to take loan either from private organizations or from foreign institutions or organization. Taking loans from private sectors and from abroad increases per capita debt of the country. Finally, the government expenditure increases to maintain high expenditures. Statista.com published the debt statistics from 2015 to 2020 and predicted for the year 2025 (Table 3).

Table 3. National debt of Bangladesh 2015-2025 (Plecher, 2021).

\begin{tabular}{|l|l|}
\hline Year & National Debt in billion US. dollars \\
\hline 2015 & 60.34 \\
\hline 2016 & 68.26 \\
\hline 2017 & 77.94 \\
\hline 2018 & 91.93 \\
\hline 2019 & 107.63 \\
\hline 2020 & 129.92 \\
\hline 2021 & 151.97 \\
\hline 2025 & 247.15 (Predicted) \\
\hline
\end{tabular}




\section{Resource Scarcity in Private Sector}

As government takes a lot of loan from private sectors, that lowers the financial strength of the private sectors, if loans become classified. In addition, inflation rate also increases that means private sectors get ill motivated to invest. Nazmul Avi Hossain of The Financial Express pointed out that this corona pandemic is adding 20-25 percent of poor people due to private sector resource deficit (Hossain, 2020).

\section{Higher Chance of Inflation}

Due to government subsidy common people get financially stable which also increases the buying capacity of common citizen. This situation results inflation which is really alarming for a developing but not yet developed economy like Bangladesh. Tasneem Raihan a researcher of the Daily star reported that Bangladesh Bureau of Statistics mentioned that 5.65 percent increase of inflation is observed during this pandemic after huge subsidy from Government (Raihan, 2020).

\section{Enlarge Government Size}

For managing and distributing the government benefits in a transparent way, Bangladesh government hires additional employees or local representatives. Above scenario not only increases the government size but also associated maintenance costs.

\section{Unemployment}

Keynesian approach has certainly increased the unemployment rate in 2020. Bangladesh Institute of Development Studies (BIDS) stated that around 13\% of those who were hired before this pandemic lost their jobs. The report also mentioned that almost $50 \%$ of job holders' incomes have been declined significantly due to this ongoing pandemic (Akter, 2020; Shovon, 2020). Anyway, common people have also developed a habit on relaxing as government is providing subsidy on basic needs.

\section{Study Limitations and Future Scope}

Although this study explores the available resources to collect evidences regarding the use of Keynesian method through technological investment in Bangladesh during this pandemic period. However, in the future, the authors plan to run a through survey in order to get more insight on aforesaid topics.

\section{CONCLUSIONS}

This study has analyzed the way that how Bangladesh government applied Keynesian method during this Covid-19 pandemic. It has been noticed that government encouraged and invested in the form of information technology to boost Bangladesh economy, however, self-benefits, corruption and money laundering diminish the actual motivation of the government. This study concluded that the Keynesian approach was most feasible for an underprivileged economy like Bangladesh but if applied with proper governance, the citizens as well as government would be benefitted more from this novel approach.

Finally, this study has also found that excessive corruption, money laundering and mismanagement of government projects are the main reasons behind the unstable position of Bangladesh economy. This study has concluded that the ruling party is certainly improving the ICT sector to bring digitalization in governance more than that of other underprivileged sectors. By doing so, the country will surely achieve all the goals of sustainable development. 


\section{ACKNOWLEDGMENTS}

The authors would like to thank American International University-Bangladesh (AIUB) authority specially, the Vice Chancellor, the Dean (FST), the Associate Dean (FST), the Director (FST) and the Department Heads (CS, graduate and undergraduate) for uplifting our moral strengths during the whole publication process amidst the coronavirus outbreak.

\section{REFERENCES}

Ahamed, F. (2021). Macroeconomic Impact of Covid-19: A case study on Bangladesh. IOSR Journal of Economics and Finance (IOSR-JEF), 12(1), 2021.

Akter, S. (2020). Covid-19 and Bangladesh: Threat of Unemployment in the Economy. 5. International EMI Entrepreneurship and Social Sciences Congress PROCEEDINGS EBOOK, 280.

Al Amin, M., Sultana, N., Saha, T., Islam, S. M., \& Kashem, M. A. (2021). Customer's Attitude toward Mobile Banking Usage: A Case Study in Bangladesh. The Journal of Asian Finance, Economics, and Business, 8(2), 419-426.

Al Omar, A., Bhuiyan, M. Z. A., Basu, A., Kiyomoto, S., \& Rahman, M. S. (2019). Privacyfriendly platform for healthcare data in cloud based on blockchain environment. Future Generation Computer Systems, 95, 511-521.

Alauddin, M. D., \& Chowdhury, M. M. (2015). Small and medium enterprise in BangladeshProspects and challenges. Global Journal of Management and Business Research.

Ali, T. O., Hassan, M., \& Hossain, N. (2021). The moral and political economy of the pandemic in Bangladesh: Weak states and strong societies during Covid-19. World Development, 137, 105216.

Amin, S. Bin, \& Rahman, S. (2019). The role of ict in energy sector: towards a digital bangladesh by 2021. In Energy Resources in Bangladesh (pp. 31-35). Springer.

Anchal. (2020). Criticism Keynesiansim. Retrieved from https://www.economicshelp.org/blog/glossary/criticism-keynesianism/

Ashraf, M., Grunfeld, H., Hoque, M. R., \& Alam, K. (2017). An extended conceptual framework to understand information and communication technology-enabled socio-economic development at community level in Bangladesh. Information Technology \& People.

Aziz, A. (2020). Digital inclusion challenges in Bangladesh: The case of the National ICT Policy. Contemporary South Asia, 28(3), 304-319.

Bangladesh Bank. (2020). Retrieved from https://www.bb.org.bd/en/index.php

Bangladesh Bank Foreign Exchange Reserve. (2021). Retrieved from https://www.bb.org.bd/en/index.php 
Bangladesh Bank Wage Remittance. (2020). Retrieved from https://www.bb.org.bd/econdata/wageremitance.php

Bangladesh Economic Indicators. (2021). $\quad$ Retrieved from https://www.theglobaleconomy.com/Bangladesh/

Barai, M. K. (2020). Development Dynamics of Remittances in Bangladesh. In Bangladesh's Economic and Social Progress (pp. 205-233). Springer.

Bartels, L. M. (2013). Political effects of the Great Recession. The ANNALS of the American Academy of Political and Social Science, 650(1), 47-76.

Berend, I. T. (2016). An economic history of twentieth-century Europe: Economic regimes from laissez-faire to globalization. Cambridge University Press.

Bhattacharyya, D. S., Shafique, S., Akhter, S., Rahman, A., Islam, M. Z., Rahman, N., \& Anwar, I. (2020). Challenges and facilitators of implementation of an information communication and technology (ICT)-based human resources management tool in the government health sector in Bangladesh: protocol for an exploratory qualitative research study. BMJ Open, 10(12), e043939.

Chowdhury, F. (2020). Virtual Classroom: To Create a Digital Education System in Bangladesh. International Journal of Higher Education, 9(3), 129-138.

Chowdhury, S. R., Sunna, T. C., \& Ahmed, S. (2021). Telemedicine is an important aspect of healthcare services amid COVID-19 outbreak: Its barriers in Bangladesh and strategies to overcome. The International Journal of Health Planning and Management, 36(1), 4-12.

Chowhan, S., \& Ghosh, S. R. (2020). Role of ICT on Agriculture and Its Future Scope in Bangladesh. Journal of Scientific Research and Reports, 20-35.

Corona Info Bangladesh. (2020). Retrieved from https://corona.gov.bd

Dietrich, S., Mahmud, M., \& Winters, M. S. (2018). Foreign aid, foreign policy, and domestic government legitimacy: Experimental evidence from Bangladesh. The Journal of Politics, 80(1), 133-148.

Douglass, J. A. (2010). Higher Education Budgets and the Global Recession: Tracking Varied National Responses and Their Consequences. Research \& Occasional Paper Series: CSHE. 4.10. Center for Studies in Higher Education.

Dutta, S., \& Smita, M. K. (2020). The impact of COVID-19 pandemic on tertiary education in Bangladesh: students’ perspectives. Open Journal of Social Sciences, 8(09), 53.

Ethiraj, G. (2020). Why Bangladesh's GDP Is Projected To Grow Despite COVID-19. Retrieved from https://www.indiaspend.com/why-bangladeshs-gdp-is-projected-to-grow-despite- 
covid-19/

Fahim, M., \& Kabir, H. (2021). Exploring the Threats of Corporate Crime as a Rising Trend of White Collar Crime in Bangladesh: An Empirical Study in the Light of Criminal Law. Journal of Asia Pacific Studies, 6(1).

Hasan, M. M., Uddin, A., Onik, M. M. H., \& Islam, M. S. (2021). Covid-19: Myths and Some Possible Arguments in Favors or in Contradictions. International Journal of Medical Science and Health Research, 5(1), 13-26.

Hasnath, S. A. (2020). Uneven Development in Bangladesh: A Temporal and Regional Analysis. In Development Studies in Regional Science (pp. 199-219). Springer.

Hossain, A. K. M. W., Raha, L. N., Faiyaz, T., Hasan, M., Nahar, N., \& Rokonuzzaman, M. (2020). Sustainable Management Strategy for Software Firms to Reduce Employee Turnover Due to Freelancing. First International Conference on Sustainable Technologies for Computational Intelligence, 197-205.

Hossain, M. N. A. (2020). Rethinking financing of SDGs: Private sector to the rescue. Retrieved from https://thefinancialexpress.com.bd/views/rethinking-financing-of-sdgs-private-sectorto-the-rescue-1605539634

Islam, M. A., Igwe, P. A., Rahman, M., \& Saif, A. N. M. (2020). Remote working challenges and solutions: Insights from SMEs in Bangladesh during the COVID-19 pandemic. International Journal of Quality and Innovation.

Islam, M. S. (2020a). Ready-made garments exports earning and its contribution to economic growth in Bangladesh. GeoJournal, 1-9.

Islam, M. S. (2020b). An Econometric Analysis on Remittance and Economic Growth in Bangladesh. International Journal of Economics and Financial Research, 6(10), 214-218.

Islam, M. S., Karia, N., Soliman, M. S. M., Fouji, M. H., Khalid, J., \& Khaleel, M. (2017). Adoption of mobile banking in Bangladesh: a conceptual framework. Review of Social Sciences, 2(8), 01-08.

IMF. (2020). World Economic Outlook, October 2020: A Long and Difficult Ascent. Retrieved from https://www.imf.org/en/Publications/WEO/Issues/2020/09/30/world-economicoutlook-october-2020

Islam, M. S., Onik, M. M. H., Hasan, M. M., \& Uddin, A. (2020). Major challenges in combating epidemics like COVID-19 in the developing countries. International Journal of Medical Science in Clinical Research and Review, 3(05), 411-430.

KPMG. (2020). China: Government and institution measures in response to COVID-19. Retrieved from https://home.kpmg/xx/en/home/insights/2020/04/china-government-and- 
institution-measures-in-response-to-covid.html

Kabir, M. R. (2021). A Unique Study of Corruption in Bangladesh. Saudi J. Humanities Soc Sci, $6(1), 18-25$.

Kano, T., Sheikh, A. M., \& Toyama, K. (2021). IT Career aspirations in Bangladesh: a Trigger for development? Information Technology for Development, 1-25.

Levanon, G. (2020). Remote Work: The Biggest Legacy Of Covid-19.

Lee, J. N., Morduch, J., Ravindran, S., Shonchoy, A., \& Zaman, H. (2021). Poverty and migration in the digital age: Experimental evidence on mobile banking in Bangladesh. American Economic Journal: Applied Economics, 13(1), 38-71.

Lewis-Beck, M. S., \& Nadeau, R. (2009). Obama and the Economy in 2008. PS, Political Science \& Politics, 42(3), 479.

Lim, C. P., Ra, S., Chin, B., \& Wang, T. (2020). Leveraging information and communication technologies (ICT) to enhance education equity, quality, and efficiency: case studies of Bangladesh and Nepal. Educational Media International, 57(2), 87-111.

López-Andreu, M., \& Verd, J. M. (2020). The Impact of Neoliberal Policies During the Great Recession on Youth Transition Regimes in Spain and the UK. Critical Sociology, 46(6), $835-850$.

Miah, M. M., \& Majumder, S. C. (2020). An Empirical Investigation of the Impact of FDI, Export and Gross Domestic Savings on the Economic Growth in Bangladesh. The Economics and Finance Letters, 7(2), 255-267.

$\begin{array}{lllll}\text { Mobile } & \text { Finance } & \text { System. } & \text { (2020). } & \text { Retrieved }\end{array}$ https://www.bb.org.bd/fnansys/paymentsys/mfsdata.php

Moniruzzaman, M. (2020). The Impact of remittances on household food security: Evidence from a survey in Bangladesh. Migration and Development, 1-20.

Naym, J., \& Hossain, M. A. (2016). Does investment in information and communication technology lead to higher economic growth: evidence from Bangladesh. International Journal of Business and Management, 11(6), 302.

Nurunnabi, M. (2019). Tax Evasion and the Role of the State Actor (s) in Bangladesh. International Journal of Public Administration, 42(10), 823-839.

Parvin, M., Asimiran, S. Bin, \& Ayub, A. F. B. M. (2021). Impact of introducing e-commerce on small and medium enterprises-a case on logistics provider. Society and Business Review.

Plecher, H. (2021). Bangladesh: National debt from 2015 to 2025. Retrieved from 
https://www.statista.com/statistics/531343/national-debt-of-bangladesh/

Peck, J., Theodore, N., \& Brenner, N. (2012). Neoliberalism resurgent? Market rule after the great recession. South Atlantic Quarterly, 111(2), 265-288.

Rabbani, K., Raihan, M. A., \& Khan, M. E. I. (2020). Constraints of Using Internet in Technical and Vocational Education: Bangladesh Context. Journal of ELT and Education, 3(2), 3342.

Rahman, M. M., Khan, S. J., Sakib, M. S., Halim, M. A., Rahman, M. M., Asikunnaby, \& Jhinuk, J. M. (2020). COVID-19 responses among university students of Bangladesh: assessment of status and individual view toward COVID-19. Journal of Human Behavior in the Social Environment, 1-20.

Raihan, T. (2020). Coronavirus paving the way for higher inflation in Bangladesh? Retrieved from https://www.thedailystar.net/opinion/news/coronavirus-paving-the-way-higherinflation-bangladesh-1944025

Ramij, M., \& Sultana, A. (2020). Preparedness of online classes in developing countries amid COVID-19 Outbreak: A Perspective from Bangladesh. Afrin, Preparedness of Online Classes in Developing Countries amid COVID-19 Outbreak: A Perspective from Bangladesh (June 29, 2020).

Rana, J., Kamruzzaman, M., Oliver, M. H., \& Akhi, K. (2021). Financial and factors demand analysis of solar powered irrigation system in Boro rice production: A case study in Meherpur district of Bangladesh. Renewable Energy, 167, 433-439.

Romana, I. E. (2020). Keynesian models of depression. Supply shocks and the COVID-19 Crisis. ArXiv Preprint ArXiv:2007.07353.

Sakil, A. H. (2018). ICT, youth and urban governance in developing countries: Bangladesh perspective. International Journal of Adolescence and Youth, 23(2), 219-234.

Sarker, M. F. H., Al Mahmud, R., Islam, M. S., \& Islam, M. K. (2019). Use of e-learning at higher educational institutions in Bangladesh. Journal of Applied Research in Higher Education.

Sarker, M. N. I., Wu, M., Liu, R., \& Ma, C. (2018). Challenges and opportunities for information resource management for E-governance in Bangladesh. International Conference on Management Science and Engineering Management, 675-688.

Sethi, N., Das, A., Sahoo, M., Mohanty, S., \& Bhujabal, P. (2020). Foreign direct investment, financial development and economic prosperity in major south Asian economies. South Asian Journal of Business Studies.

Seymour, G., Malapit, H., \& Quisumbing, A. (2020). Measuring time use in developing country 
agriculture: Evidence from Bangladesh and Uganda. Feminist Economics, 26(3), 169-199.

Shovon, F. R. (2020). Covid-19: Employment takes a serious hit in Bangladesh. Retrieved from https://www.dhakatribune.com/health/coronavirus/2020/09/23/employment-during-aneconomy-ravaged-by-covid-19

Solaiman, S. M. (2018). Captured by evils-combating black money, corruption and money laundering in Bangladesh: The dog must bark to keep predators away. Journal of Money Laundering Control, 21(3), 264-289.

Soll, J. (2020). For a New Economic History of Early Modern Empire: Anglo-French Imperial Codevelopment beyond Mercantilism and Laissez-Faire. The William and Mary Quarterly, 77(4), 525-550.

Srouji, J. (2020). Digital Payments, the Cashless Economy, and Financial Inclusion in the United Arab Emirates: Why Is Everyone Still Transacting in Cash? Journal of Risk and Financial Management, 13(11), 260.

Stern, C. W., \& Deimler, M. S. (2006). The Boston consulting group on strategy: Classic concepts and new perspectives. John Wiley \& Sons.

The World Bank. (2020). COVID-19 to Plunge Global Economy into Worst Recession since World War II. https://www.worldbank.org/en/news/press-release/2020/06/08/covid-19-toplunge-global-economy-into-worst-recession-since-world-war-ii

The World Bank. (2020). Poverty and Shared Prosperity 2020. Retrieved from https://www.worldbank.org/en/publication/poverty-and-shared-prosperity

Tobin, J. (1975). Keynesian models of recession and depression. The American Economic Review, 65(2), 195-202.

UNICEF. (2020). Students in Bangladesh adjust to remote learning via national TV during COVID-19 lockdown. Retrieved from https://www.unicef.org/bangladesh/en/stories/students-bangladesh-adjust-remote-learningnational-tv-during-covid-19-lockdown

Uttom, S., \& Rozario, R. R. (2019). Rich-poor gap increases in Bangladesh. Retrieved from https://www.ucanews.com/news/rich-poor-gap-increases-in-bangladesh/84334\#

Vickrey, W. (1948). Limitations of Keynesian economics. Social Research, 403-416.

Winters, M. S., Dietrich, S., \& Mahmud, M. (2017). Perceptions of foreign aid project quality in Bangladesh. Research \& Politics, 4(4), 2053168017735200.

Yesmin, S., Paul, T. A., \& Uddin, M. M. (2019). bKash: Revolutionizing mobile financial services in Bangladesh? In Business and Management Practices in South Asia (pp. 125- 
148). Springer.

Zhao, X., Yu, B., Liu, Y., Chen, Z., Li, Q., Wang, C., \& Wu, J. (2019). Estimation of poverty using random forest regression with multi-source data: A case study in Bangladesh. Remote Sensing, 11(4), 375.

Zakirdjanovich, L. S. (2021). Issues Of Development Of Freelance Activities In The Context Of Development Of The Digital Economy. International Journal of Progressive Sciences and Technologies, 24(1), 223-228.

Zaman, A. (2019). Rapid digitalisation and a high rate of educated unemployment has made Bangladesh the second largest exporter of online labour.

\section{Copyrights}

Copyright for this article is retained by the author(s), with first publication rights granted to the journal. This is an open-access article distributed under the terms and conditions of the Creative Commons Attribution license (http://creativecommons.org/licenses/by/4.0/). 